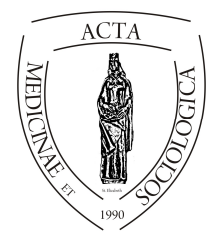

Acta Medicinae et

Sociologica (2020)

UNIVERSITY OF

DEBRECEN

Vol. 11., Különszám. (110-125)

FACULTY OF

HEALTH

doi:

NYÍREGYHÁZA

\title{
Az uszodai infrastruktúra vizsgálata az Észak-alföldi régióban
}

\author{
Kosztin Nikolett $^{1}$, Balatoni Ildikó ${ }^{2}$ \\ ${ }^{1}$ ügyvivő szakértő, Debreceni Egyetem Klinikai Központ Minőségügyi Iroda, 4032 Debrecen, Nagyerdei krt.98. \\ ${ }^{2}$ operatív igazgató, Debreceni Egyetem Klinikai Központ Operatív Igazgatóság, 4032 Debrecen, Nagyerdei krt.98.
}

\begin{tabular}{|c|c|}
\hline INFO & ABSTRACT \\
\hline $\begin{array}{l}\text { Dr. Balatoni Ildikó } \\
\text { balatoni@med.unideb.hu }\end{array}$ & \multirow[b]{2}{*}{$\begin{array}{l}\text { Abstract. Swimming is one of the popular sports that can be } \\
\text { done at any age in addition to it being a health-promoting } \\
\text { form of exercise. Due to the physical inactivity of a signifi- } \\
\text { cant proportion of our current society, researchers have been } \\
\text { looking at how the population can be persuaded to exercise } \\
\text { sports regularly, which also included examining the impact } \\
\text { of built environment on sporting habits. In our research, we } \\
\text { investigated } 34 \text { swimming pools in the North Great Plain } \\
\text { region, using a telephone interview-based questionnaire } \\
\text { method. We reviewed the dates when the swimming pools } \\
\text { were inaugurated, the goals set during the establishment, and } \\
\text { the number and length of the pools. We analyzed how sport- } \\
\text { ing activities such as school swimming, residential swim- } \\
\text { ming, physiotherapy, training, and competitions appear in } \\
\text { the timetable, and how the opening hours affect the usage of } \\
\text { the pools by the population. } \\
\text { It can be stated that based on the health indicators of the } \\
\text { counties concerned, it would be important to educate for a } \\
\text { healthy lifestyle, and also to ensure the possibility of swim- } \\
\text { ming. At the same time, the infrastructure currently avail- } \\
\text { able is scarce and as such the continuation of the swimming } \\
\text { pool building program is of paramount importance. }\end{array}$} \\
\hline $\begin{array}{l}\text { Keywords: } \\
\text { sport, region, swimming } \\
\text { pools, school swimming, } \\
\text { community swimming }\end{array}$ & \\
\hline $\begin{array}{l}\text { Kulcsszavak: } \\
\text { sport, régió, uszoda, } \\
\text { iskolai úszás, lakossági } \\
\text { úszás }\end{array}$ & $\begin{array}{l}\text { Absztrakt: Az úszás azon közkedvelt sportágak egyike, } \\
\text { amely amellett, hogy egészséget megőrző mozgásforma, } \\
\text { bármely életkorban űzhető. Jelen társadalmunk jelentős } \\
\text { hányadának fizikai inaktivitása miatt kutatók számos irány- } \\
\text { ból vizsgálták, hogy miként lehetne rendszeres sportolásra } \\
\text { bírni a lakosságot, többek között az épített környezet sporto- } \\
\text { lási szokásokra gyakorolt hatásai is elemzésre kerültek. } \\
\text { Kutatásunk során az Észak-alföldi régió } 34 \text { uszodáját tanul- } \\
\text { mányoztuk, telefonos interjú alapján végzett kérdöíves mód- } \\
\text { szerrel. Áttekintettük az uszodák átadásának időpontjait, a } \\
\text { létesítéskor megfogalmazott célokat, a medencék számát, }\end{array}$ \\
\hline
\end{tabular}


hosszát. Elemeztük, hogy az egyes sportfoglalkozások, mint iskolai úszás, lakossági úszás, gyógytorna, edzés, versenyek hogyan jelennek meg az időbeosztásban, valamint, hogy a nyitva tartás miként befolyásolja a lakosság által történő igénybevétel lehetőségét.

Megállapítható, hogy az érintett megyék egészségügyi mutatói alapján fontos lenne az egészséges életmódra nevelés, ehhez kapcsolódóan az úszás lehetőségének biztosítása is. Ugyanakkor a jelenleg rendelkezésre álló infrastruktúra kevés, emiatt az uszodaépítési program folytatása kiemelt jelentőségü.

A publikáció elkészítését az EFOP-3.6.2-16-2017-00003 számú projekt támogatta. A projekt az Európai Unió támogatásával, az Európai Szociális Alap társfinanszírozásával valósult meg.

\section{Bevezetés}

Napjainkban a fizikai inaktivitás a negyedik vezető halálok (Kohl, Craig és munkatársai 2012). A világ lakosságának 31\%-a nem teljesíti a fizikai aktivitásra vonatkozó minimális ajánlást sem. A fizikai inaktivitás nő az életkor előrehaladtával, és magasabb a nőknél, mint a férfiaknál (Hallal, Anderson és munkatársai 2012). Ahhoz, hogy a fizikai aktivitást a népesség körében javítani tudjuk, ismernünk kell azokat a tényezőket, amelyek befolyásolják az egyének ilyen irányú elköteleződését (Barranowski, Anderson és Carmack 1998). Az egészséges életmód a gyermekkorban alapozódik meg. Korábbi vizsgálatok már rámutattak, hogy az egyén sportolási szokásait egyebek között alapvetően meghatározza, hogy fiatalkorban milyen családi mintát látott és hogy ö maga sportolt-e rendszeresen (Sallis, Prochaska és Taylor 1999; Edwardson és Gorely 2010). Az elmúlt évtizedben több kutató figyelme arra irányult, hogy milyen hatással van az épített környezet a lakosság sportolási szokásaira és fizikai aktivitására (Brug, van Lenthe és Kremers 2006; Brownson, Hoehner és munkatársai 2009; Cauwenberg, Bourdeaudhuij és munkatársai 2011). Ebből a szempontból a fizikai környezetbe beleértendő a lakókörnyezet kialakítása (pl. a járdák jelenléte), a fizikai aktivitásra alkalmas helyszínekhez történő eljutás lehetőségei és a biztonságos környezeten túl, a létesítmények jelenléte is (Davison és Lawson 2006; Wendel-Vos, Droomers és munkatársai 2007).

Korábbi munkánkban rámutattunk, hogy az úszás olyan fizikai aktivitás, amely nemcsak fiatalkorban kedvelt, de még idős korban is népszerü marad (Balatoni, Kith és Csernoch 2016). Ennek egyik fontos oka, hogy az úszás nem csak mint sport, hanem mint egészségünket megőrző mozgásforma is ismert. Fontos szerepet játszik az izomrendszer fejlesztésében, a mozgásszervi rendellenességek javításában, rendkívül pozitív hatással van a légzőszervi müködésre, a vízben végzett örömteli testmozgás a pszichoszomatikus betegségek kialakulása ellen is védelmet jelent.

Az Európai Unió és a magyar kormány kiemelt területként tekint a sportra és a sporthoz kapcsolódó infrastrukturális beruházásokra. A Nemzeti Sportstratégiában (2007) megfogalmazott cél az úszásoktatás lehetőségének megteremtése minden 
gyermek számára. Kutatásunkban arra kerestük a választ, hogy az Észak-alföldi régió már meglévő uszodái mennyire képesek kiszolgálni az igényeket.

\section{Anyag és módszerek}

Vizsgálatunk adatbázisát a Megyei Kormányhivataloktól kapott nyilvántartásra alapozva, 2017-ben összegyüjtöttük az Észak-alföldi régió azon uszodáit, amelyekben iskolai úszásoktatás illetve lakossági úszás történik. Adatgyüjtésünket kérdőíven alapuló telefonos interjúkkal folytattuk, melyben a létesítményi illetve kihasználtsági adatokra kérdeztünk rá. Elemzésünkbe 34 intézmény került bevonásra. A kitöltött kérdőívek feldolgozása EvaSys programmal történt. A regionális és megyei adatok forrásai egyrészt a KSH területi adatbázisa, másrészt az Oktatási Hivatal által közzétett információk voltak.

\section{Eredmények}

Az Észak-alföldi régió Debrecennel, mint központtal Szabolcs-Szatmár-Bereg, HajdúBihar, valamint Jász-Nagykun-Szolnok megyét foglalja magába. Lakónépessége 1460 096 fó, mely alapján Magyarország régióinak sorrendjében a 2. helyet foglalja el. Ugyancsak második az élveszületések és a halálozások számát tekintve is. Az átlagéletkor vonatkozásában a második legfiatalabb régiónak tekinthető (férfiak: 39,4 év, nők: 43,5 év), ugyanakkor a születéskor várható élettartamot vizsgálva a harmadik legkedvezőtlenebb értéket mutató régió (férfiak: 71,88 év, nők: 78,66 év) (KSH 2019).

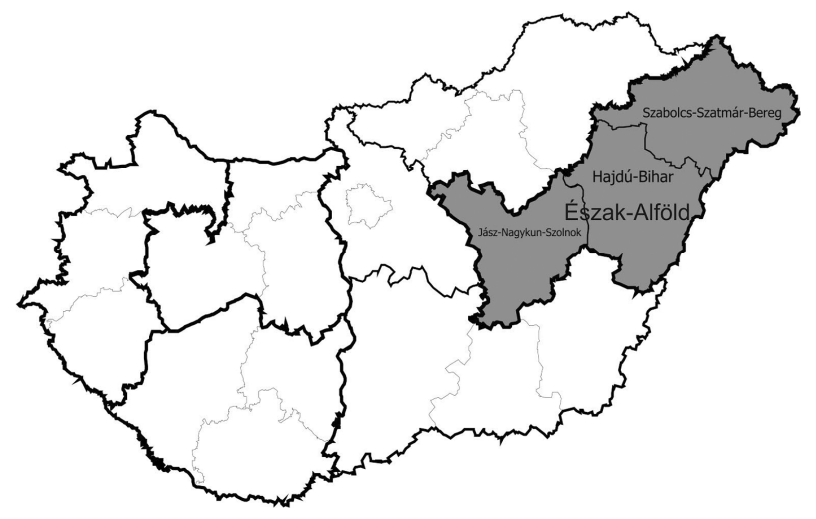

Forrás: Saját szerkesztés

1. ábra. Az Észak-alföldi régió elhelyezkedése Magyarországon

Ha a megyei adatokat vizsgáljuk, megállapítható, hogy Hajdú-Bihar megyét fogyó népesség és elöregedő lakosság jellemzi (KSH, 2017). Mind az idősebb (60+ éves) 
korcsoportban, mind 60 év alatt a keringési rendszer betegsége a vezető halálok. A megyében 82 település, 21 város és 61 község található.

Szabolcs-Szatmár-Bereg megye az ország legfiatalabb korösszetételü megyéje. Településszerkezetét tekintve kiemelendők az aprófalvak, 229 települése közül mindösszesen 28 város. A népesség 46\%-a községekben él, melyek közül száznak a népessége kevesebb, mint ezer fö. A születéskor várható élettartam nem éri el az országos átlagot (KSH, 2017).

Jász-Nagykun-Szolnok megye 78 településéből 22 város. A lakosságának 18\%-a 1000 fő alatti népességü településen él. Itt is az öregedő, fogyó népesség jellemző. A keringési rendszer betegségei okozta halálozás gyakorisága mindkét nem esetében meghaladja az országos átlagot (J-N-SZ megyei Kormányhivatal, 2018). A kutatásunk szempontjából releváns adatokat az 1.sz. táblázatban foglaltuk össze.

\begin{tabular}{|l|c|c|c|c|c|c|}
\hline & Településszám (db) & Lakosságszám (fö) & $\begin{array}{c}\text { 5-14 éves korú } \\
\text { lakosság (fö) }\end{array}$ & $\begin{array}{c}\text { Általános iskolák } \\
\text { száma (db) }\end{array}$ & $\begin{array}{c}\text { Bevont uszodák } \\
\text { száma (db) }\end{array}$ & $\begin{array}{c}\text { Új uszodák száma* } \\
\text { (db) }\end{array}$ \\
\hline Hajdú-Bihar megye & 82 & 530464 & 52817 & 188 & 15 & 1 \\
\hline $\begin{array}{l}\text { Jász-Nagykun- } \\
\text { Szolnok megye }\end{array}$ & 78 & 371271 & 59853 & 153 & 14 & 2 \\
\hline $\begin{array}{l}\text { Szabolcs-Szatmár- } \\
\text { Bereg megye }\end{array}$ & 229 & 558361 & 36474 & 246 & 5 & 4 \\
\hline
\end{tabular}

Forrás: $\mathrm{KSH}, 2017$

* Köznevelési Infrastruktúra Fejlesztési Program keretében megvalósuló tanuszoda fejlesztések;

\section{1. táblázat. Az Észak-alföldi régióra jellemző adatok}

A kutatásunkba összesen 34 fedett illetve nyitott uszodát vontunk be, melyek Északalföldi régióban történő földrajzi elhelyezkedését a 2. ábra szemlélteti.

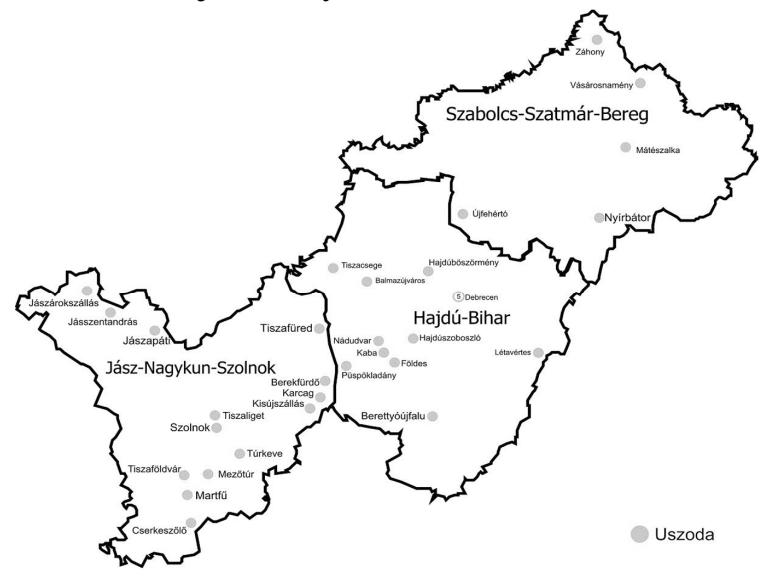

Forrás: Saját szerkesztés

2. ábra. Az Észak-alföldi régió vizsgálatba bevont 34 uszodájának területi elhelyezkedése

A kérdőívünk első kérdésével arra kerestük a választ, hogy a megkeresett uszodában van-e és ha igen, akkor mennyi olyan úszómedence, amely iskolai illetve lakossági úszás biztosítására is alkalmas. 
A megkérdezett uszodák többsége (58,8\%) egy ilyen, 35,3\%-uk két medencével rendelkezik és csak 1-1 olyan uszoda van, ahol három vagy akár több ilyen medence is található (3. ábra).

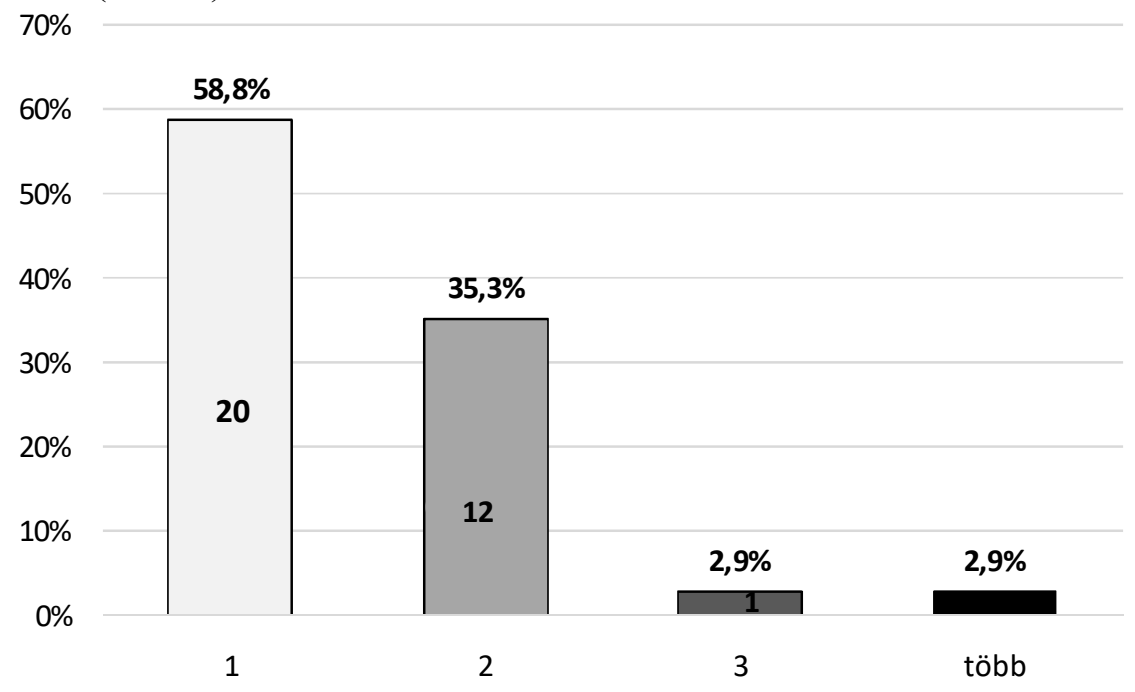

Forrás: Saját szerkesztés

3. ábra. A vizsgálatba bevont uszodák úszásra alkalmas medencéinek száma

Kíváncsiak voltunk arra is, hogy mikor épültek ezek a létesítmények. A kapott eredményekből megállapítottuk, hogy a legtöbb uszoda (53\%) még a rendszerváltás, azaz 1989 előtt épült, ezekben azóta maximum felújításra volt lehetőség. Összesen 7 olyan uszoda van, amely 1990 és 2006 között épült, míg 9 (26\%) 2007-2013 között.

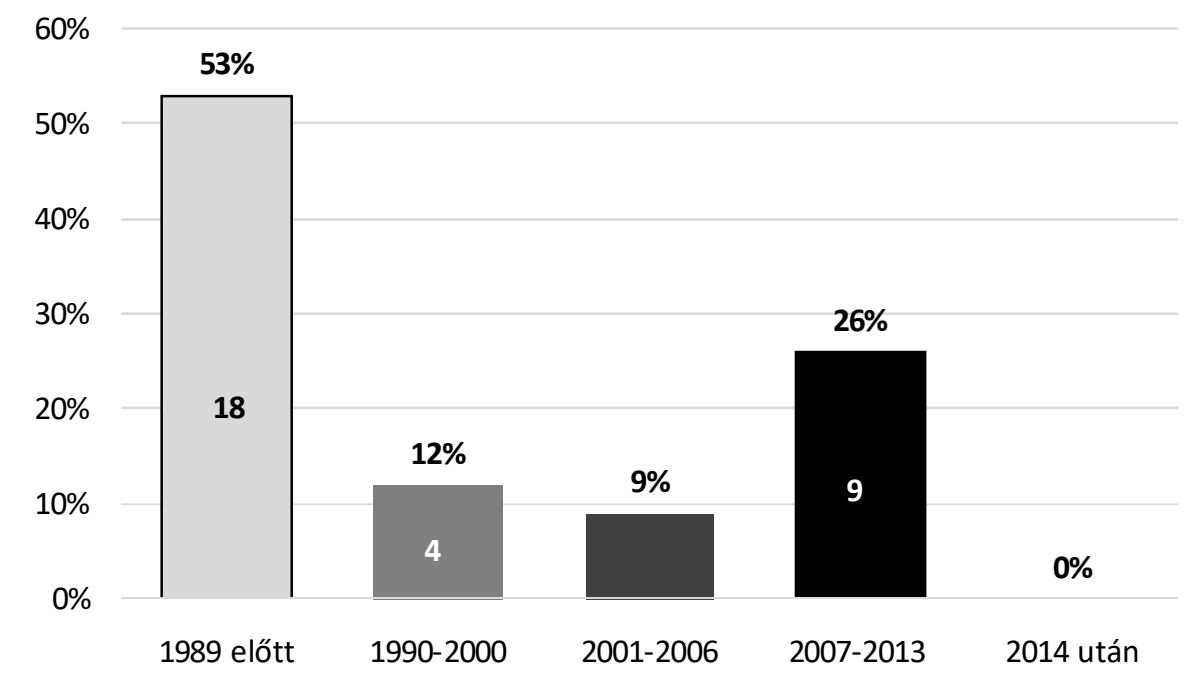

Forrás: Saját szerkesztés

4. ábra. Az uszodák építésének időpontjai 
A kutatásba bevont uszodák között nem volt olyan, amit 2014 után építettek, de az elfogadott Nemzeti Köznevelési Infrastruktúra Fejlesztési Program keretében 25 új tanuszoda építésére kerül sor. Az uszodák elhelyezkedését mutatja az 5. ábra.

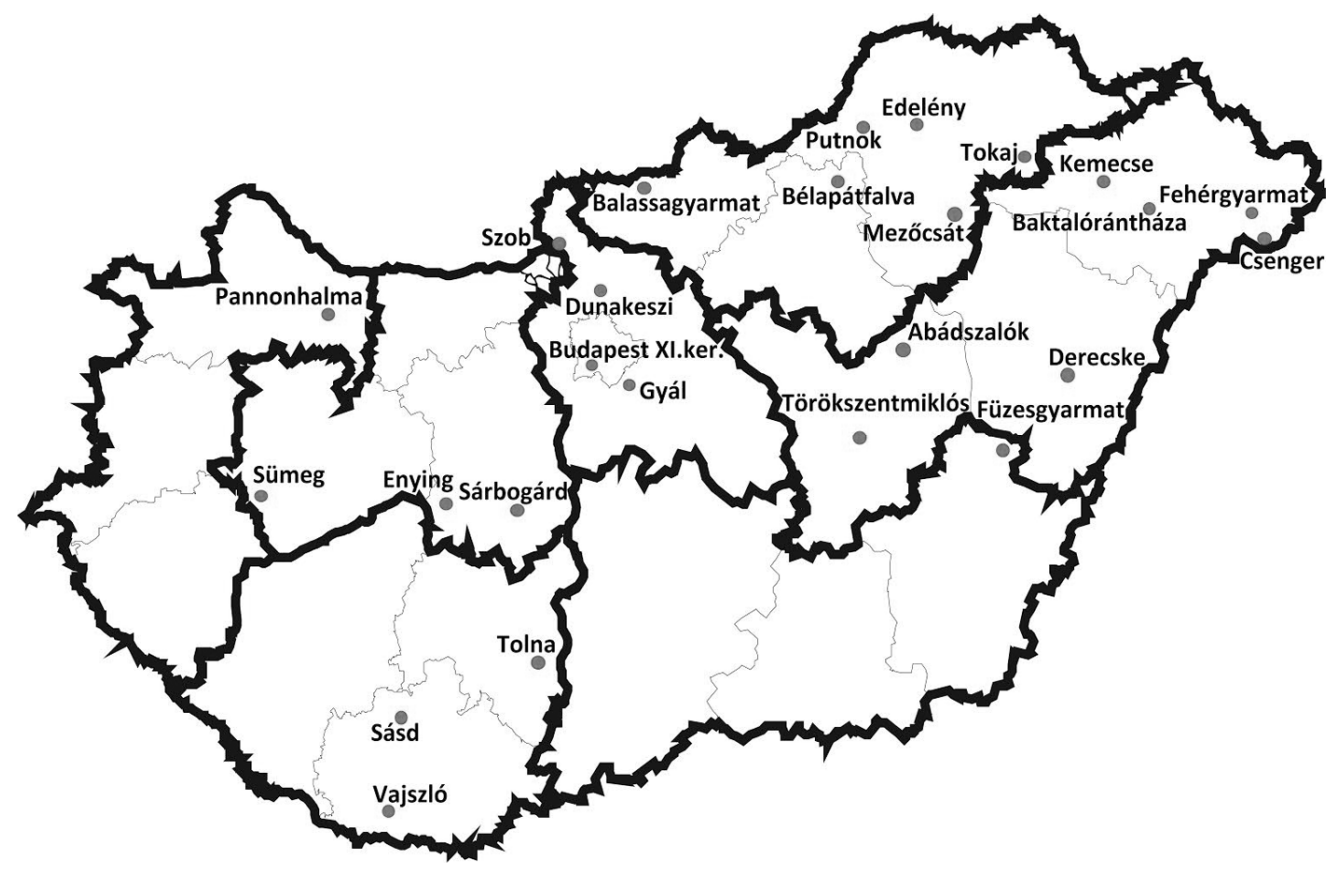

Forrás: Saját szerkesztés

5. ábra. Nemzeti Köznevelési Infrastruktúra Fejlesztési Program keretében megvalósuló tanuszoda fejlesztések - $2016(25 \mathrm{db})$

Az uszodák létrehozásának okait vizsgálva megállapíthatjuk, hogy Hajdú-Bihar és Jász-Nagykun-Szolnok megyében az elsődleges cél a lakossági úszás biztosítása volt, míg Szabolcs-Szatmár-Bereg megyében alapvetően az iskolai úszás színterét szerették volna megteremteni (6. ábra). A régió 2 megyéjében (Hajdú-Bihar és Jász-NagykunSzolnok) alapítási célként megjelent a helyi sportegyesületek kiszolgálása is.

Megkérdezve, hogy melyek azok az események, amelyek leggyakrabban kerülnek megrendezésre a létesítményben, azt a választ kaptuk, hogy leginkább az iskolai úszásnak, a lakossági úszásnak és a gyógytornának szolgálnak helyszínül az uszodák (7. ábra). Ezek mellett úszásoktatás is van az uszodákban, de természetesen az egyesületi úszóversenyek, úszóedzések és a babaúszás is helyet kapnak. 


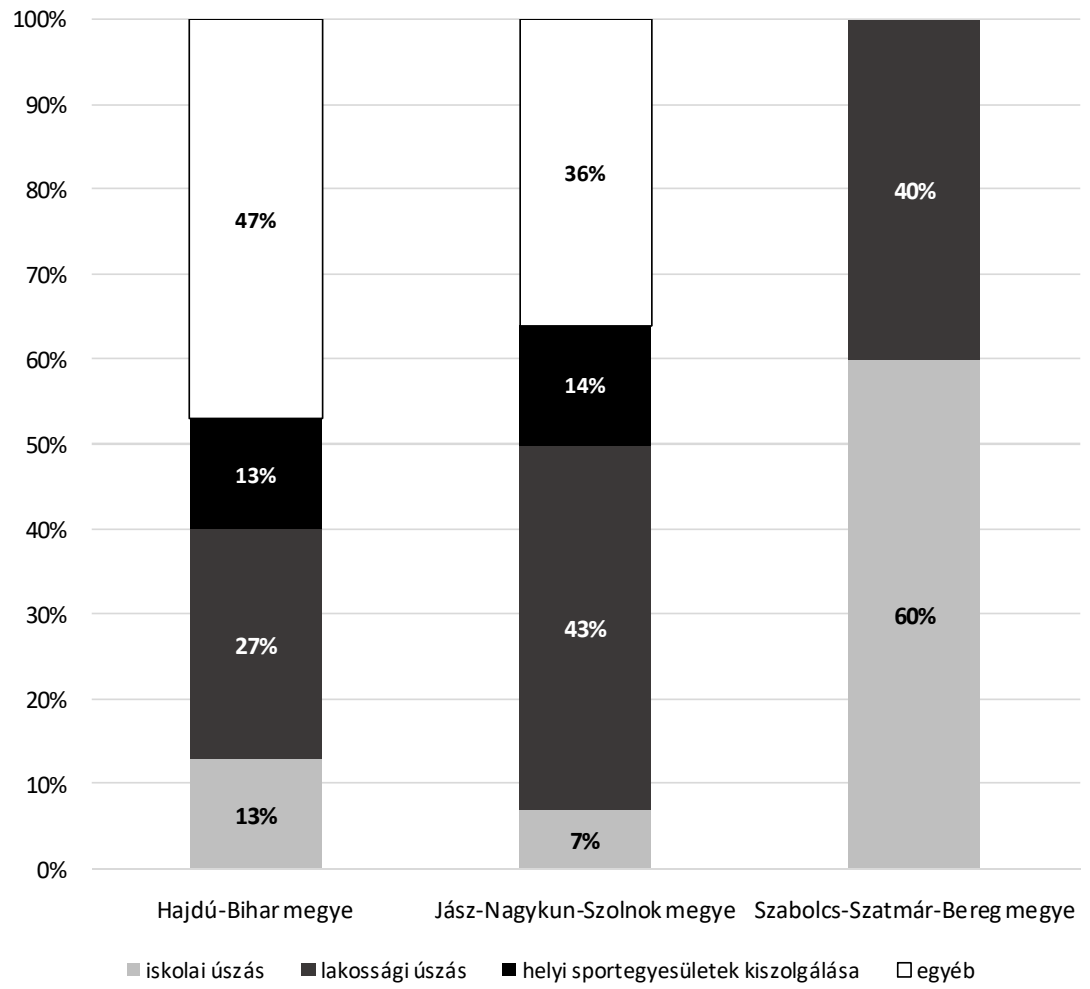

Forrás: Saját szerkesztés

6. ábra. Az uszodai infrastruktúra létrehozásának céljai az Észak-alföldi régió 3 megyéjében

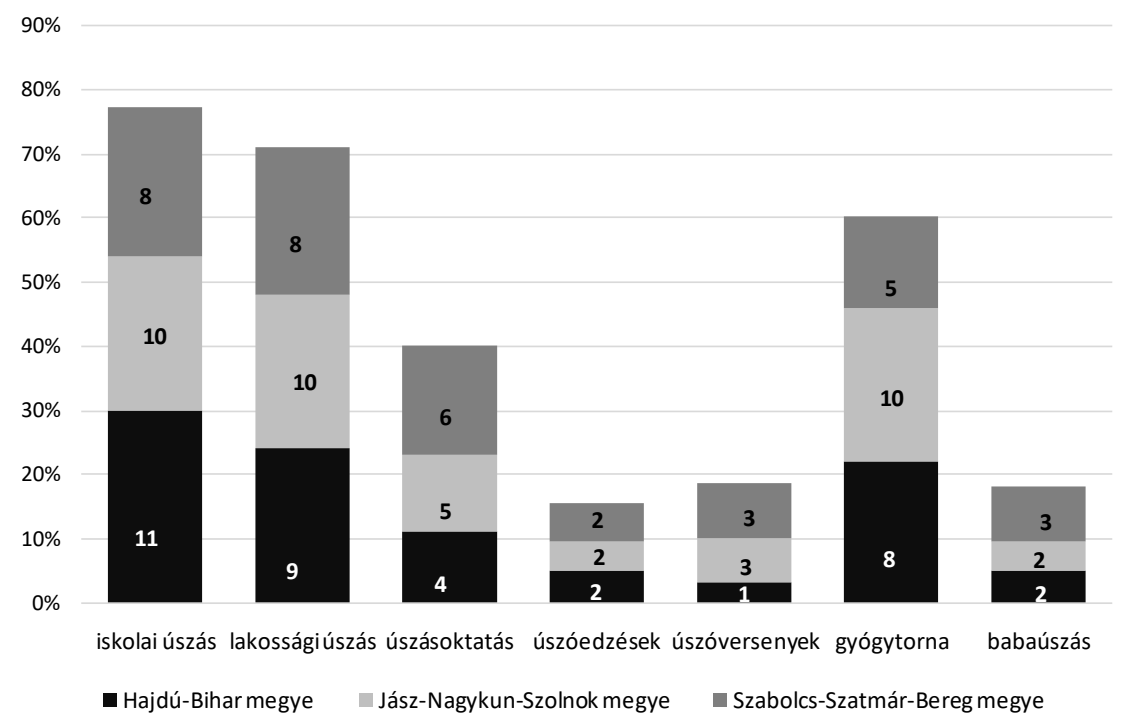

Forrás: Saját szerkesztés

7. ábra. Az uszodákban folyó tevékenységek megoszlása megyénként 
A létesítmények tulajdonosi körét vizsgálva elmondható, hogy az uszodák alapvetően önkormányzati tulajdonban vannak ( $25 \mathrm{db}), 7$ uszoda adta azt a választ erre a kérdésre, hogy magántulajdonban van és mindösszesen 1 van iskolai tulajdonban.

Ez a válasz nem azt jelenti, hogy nincsenek olyan uszodák, amelyek iskolák épületében müködnének, azonban mindegyikük elmondta, hogy ők csak a helyet biztosítják, minden más tekintetben az önkormányzat az, aki helyt áll és döntést hoz az uszoda vonatkozásában.

Ezután annak elemzésére tértünk át, hogy hány méter hosszúak a medencék. A 8. ábrán is jól látszik, hogy leginkább 25 méter hosszú medencékkel találkoztunk (16 db), de 9 uszoda rendelkezik 33 méteres és öt 50 méteres verseny úszómedencével.

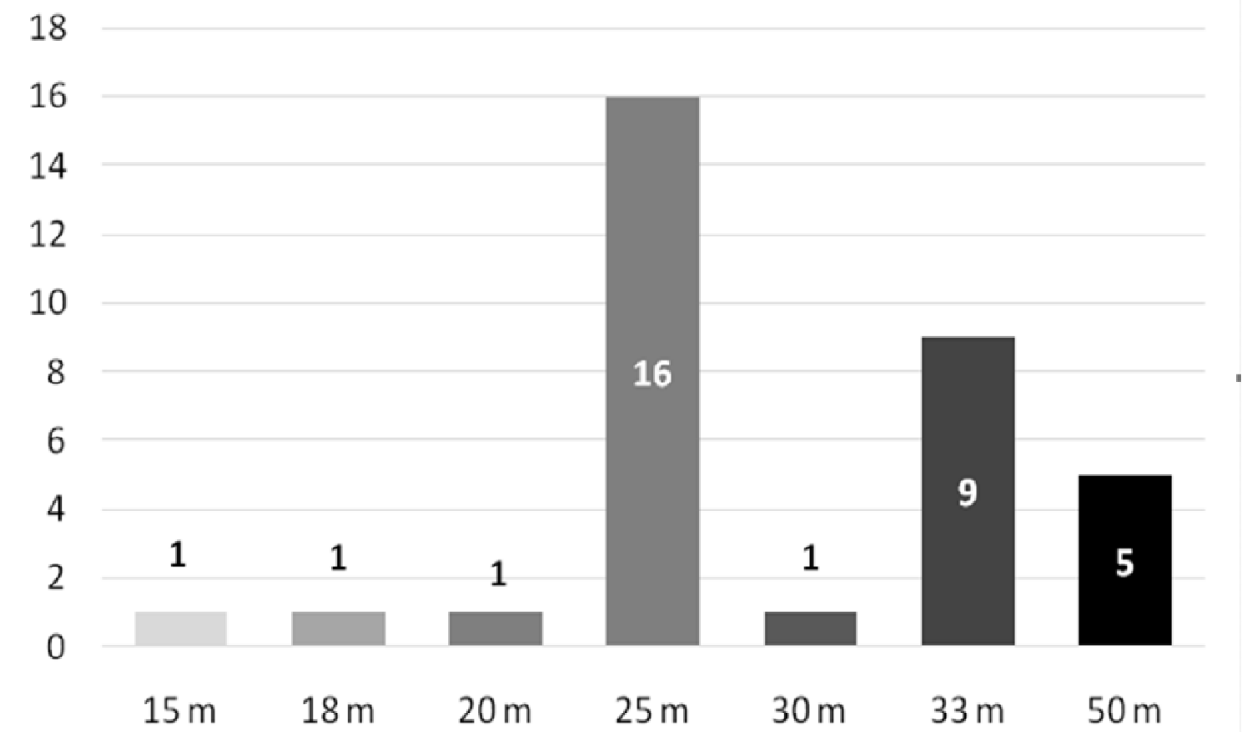

Forrás: Saját szerkesztés

8. ábra. A leghosszabb úszásra alkalmas medencék megoszlása (db)

Az uszodák kihasználtságának tanulmányozása érdekében a nyitás és zárás időpontját is megvizsgáltuk, külön a hétköznapokra és külön a hétvégi időszakra is. Ezek alapján az látható, hogy hétköznap az uszodák 30\%-a nyit ki 8 órakor, míg 42\%-uk már 7 órakor vagy ezt megelőzően nyitva van (9.a-b. ábra). Ugyanezt megvizsgálva hétvégén azt látjuk, hogy 7 órakor vagy az elött az uszodák 26\%-a, 45\%-uk 8 órakor nyit ki. 
$50 \%$

$45 \%$

$40 \%$

$35 \%$

$30 \%$

$25 \%$

$20 \%$

$15 \%$

$10 \%$

$5 \%$

$0 \%$

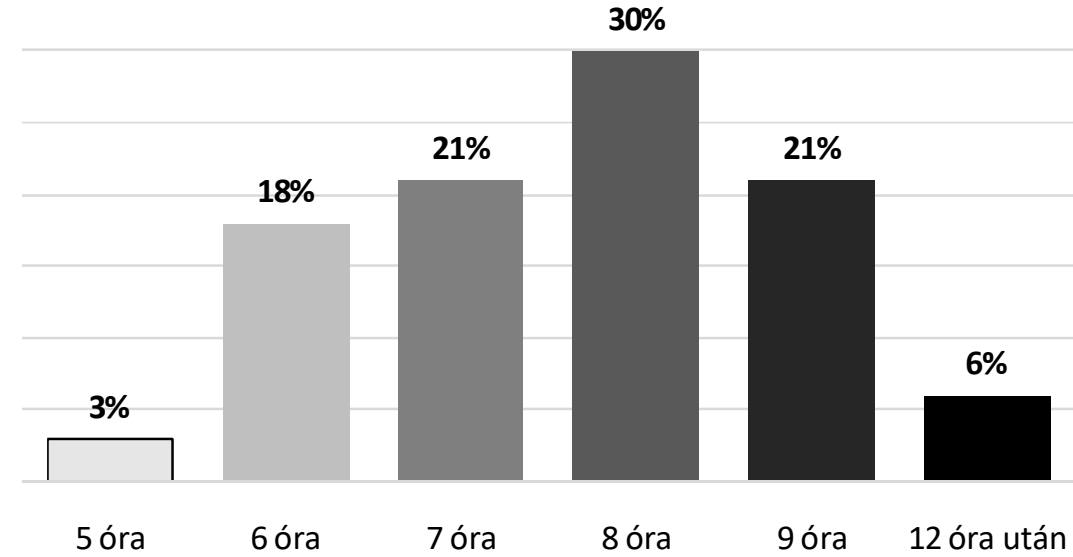

Forrás: Saját szerkesztés

9.a. ábra. Uszodák hétköznapi nyitása

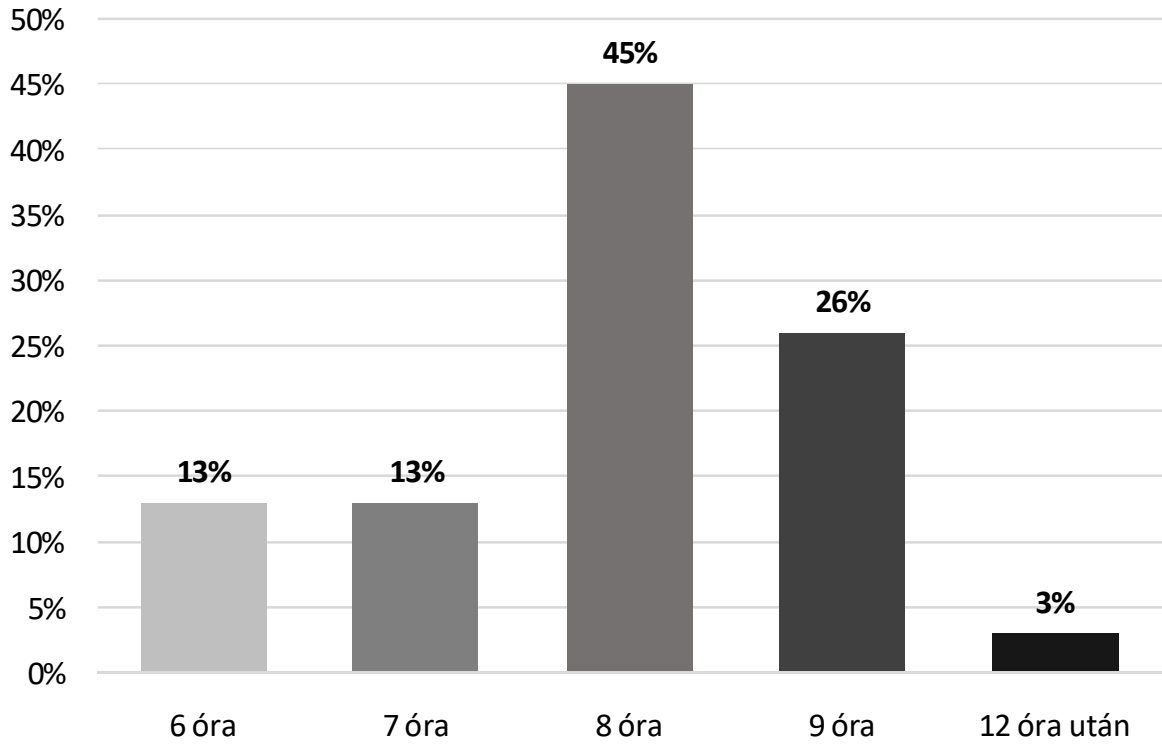

Forrás: Saját szerkesztés

9.b. ábra. Uszodák hétvégi nyitása 
Az uszodák zárásával kapcsolatban alapvetően elmondható, hogy a legtöbb uszoda (60-64\%) este 20 óráig tart nyitva legyen az hétköznap vagy hétvége (10.a-b. ábra). De azt is kijelenthetjük, hogy hétköznap 21\%-uk, szombaton pedig 13\%-uk tart nyitva 21 illetve 22 óráig, ezzel is biztosítva a lakosság számára az úszás lehetőségét.

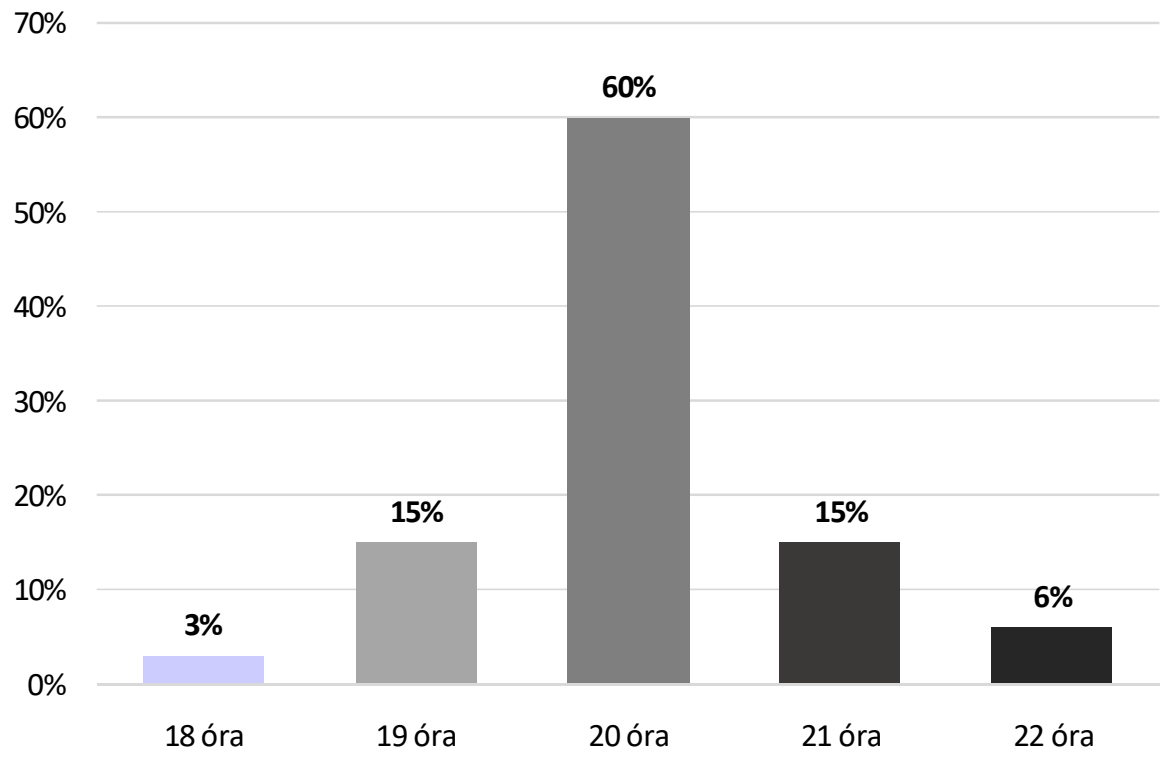

Forrás: Saját szerkesztés

10.a. ábra. Uszodák hétköznapi zárása

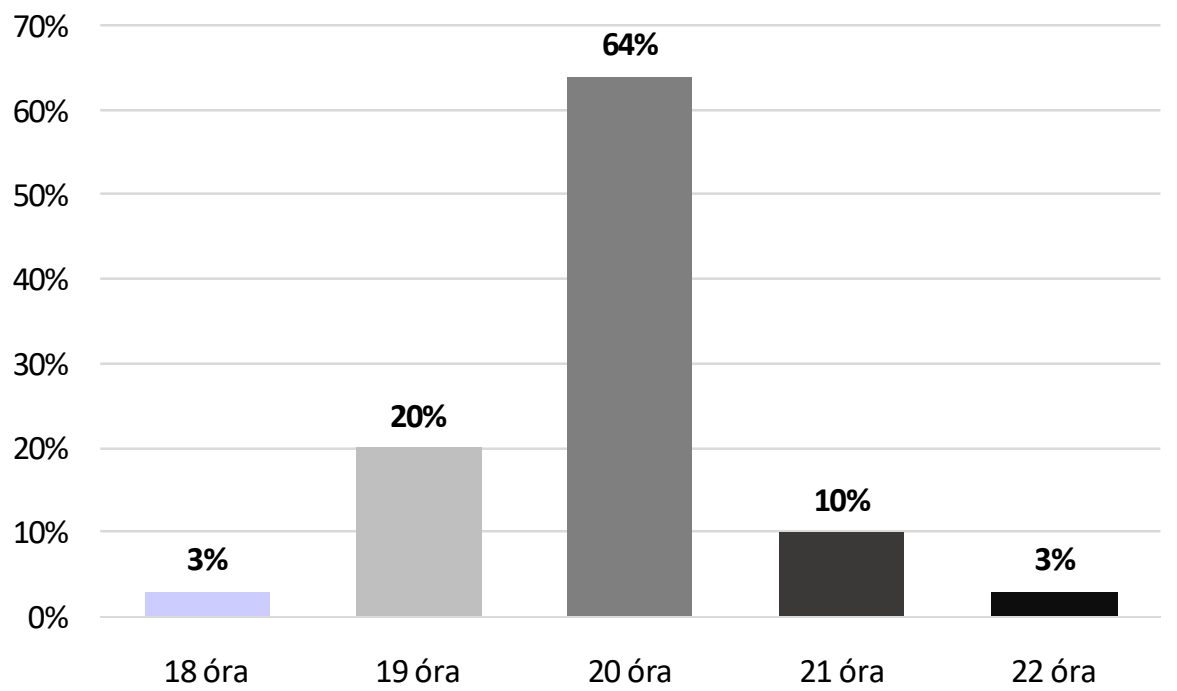

Forrás: Saját szerkesztés

10.b. ábra. Uszodák szombati zárása 
Vasárnap a zárás a szombatihoz hasonló, azzal a különbséggel, hogy nincs 22 óráig nyitva tartó létesítmény, $10 \% 21$ órakor, $61 \% 20$ órakor bezár.

Rákérdeztünk arra is, hogy milyen százalékban kihasználtak a létesítmények hétköznapokon illetve hétvégén. Ha a hétköznapi kihasználtságot nézzük elmondható, hogy általában (legyen az délelőtti, délutáni vagy esti időszak) 60-70\%-ban kihasználtak a létesítmények, de van több olyan uszoda is, amelyik azt vallotta, hogy 100\%-ban kihasznált a kapacitásuk hétköznap (11. ábra).

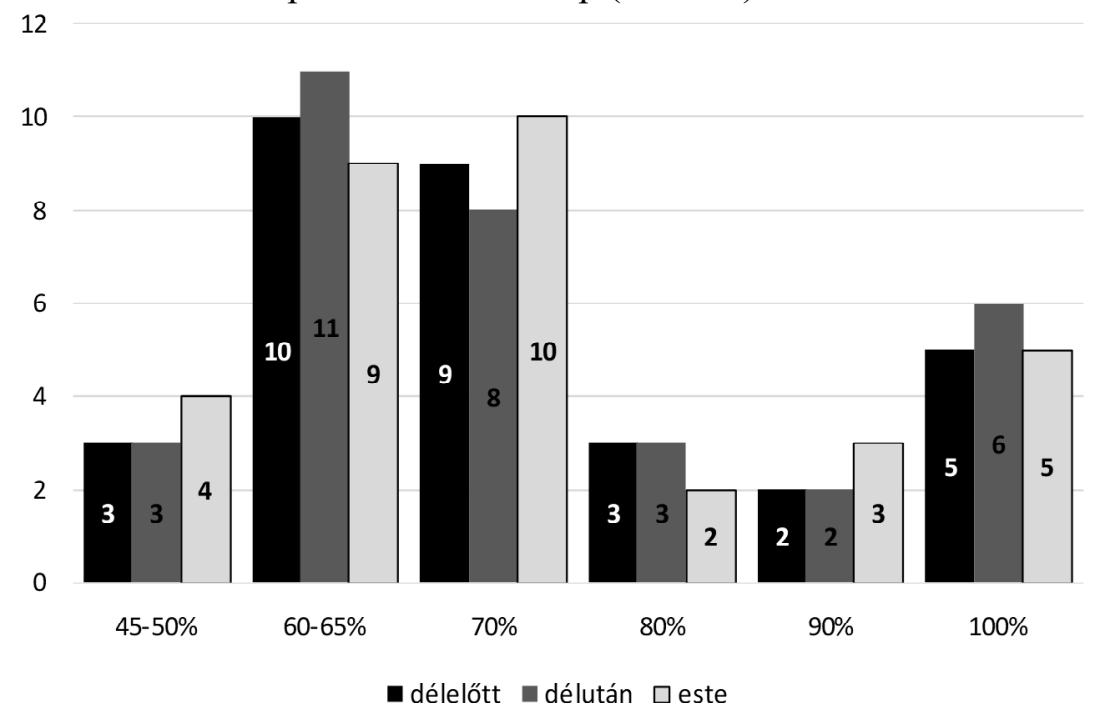

Forrás: Saját szerkesztés

11. ábra. Uszodák kihasználtsága hétköznap - az intézmény saját megítélése alapján

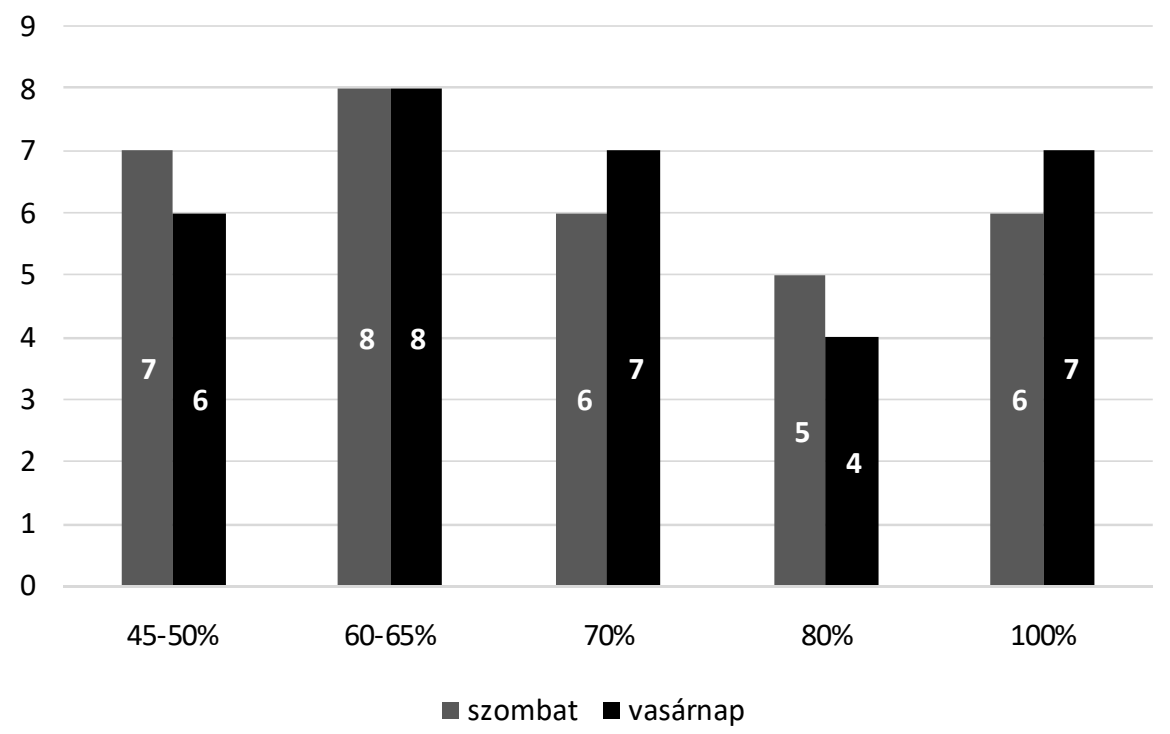

Forrás: Saját szerkesztés

12. ábra. Uszodák kihasználtsága hétvégén - az intézmény saját megítélése alapján 
A hétvégi kihasználtság árnyaltabb képet mutat, ugyanis a 45\%-os kihasználtságtól a 100\%-os kihasználtságig valamennyi válasz előfordult (12. ábra).

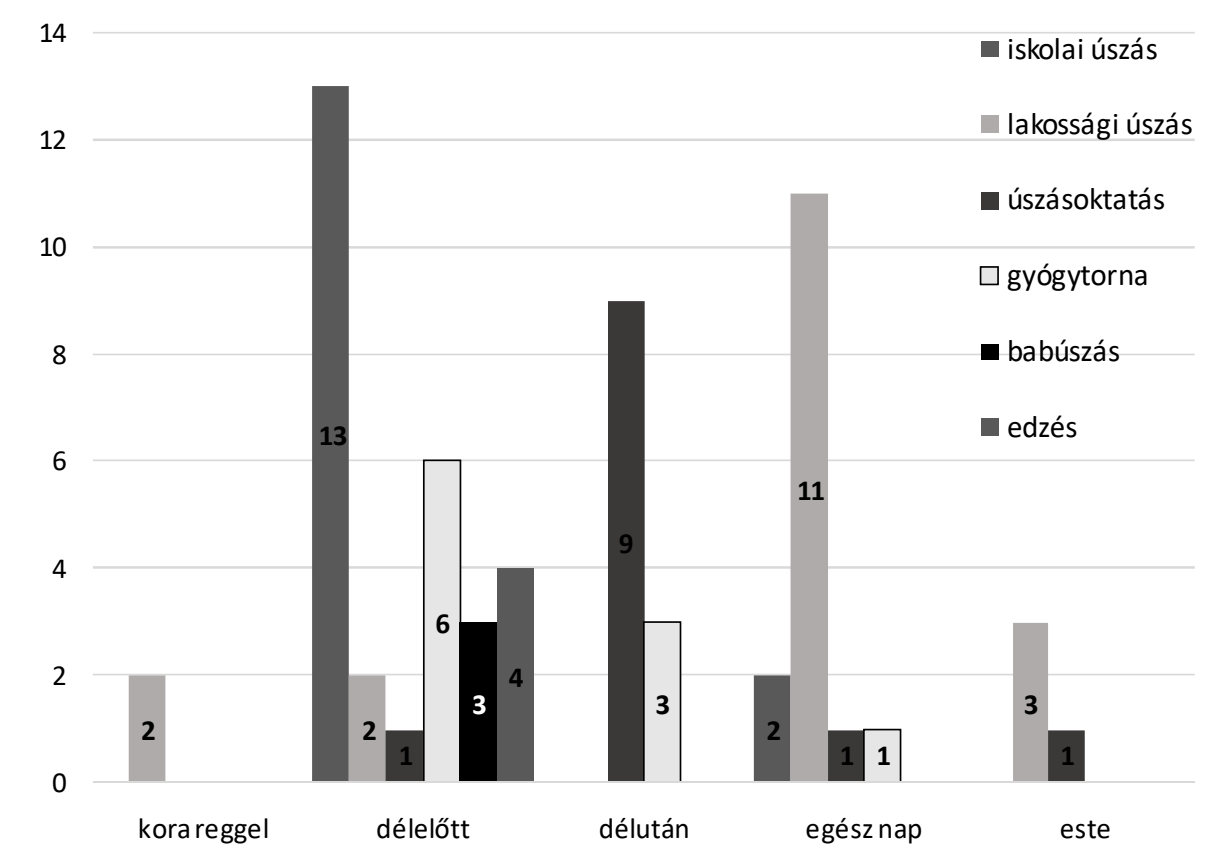

Forrás: Saját szerkesztés

13. ábra. Úszófoglalkozások időbeni megoszlása hétköznap (db) - ennél a kérdésnél több válasz megadására is lehetőség volt.

Vizsgálatunk során arra is kerestük a választ, hogy az egyes napszakokban hogyan oszlanak el a különbözö úszásfoglalkozások (13. ábra). Az uszodák 36,66 \%-a mondta azt, hogy egész nap lehetősége van a lakosságnak használni a létesítményt, további 5\% kora reggel illetve $8 \%$ este biztosít lehetőséget lakossági úszás céljára. Az uszodák 38\%-a délelőtt iskolai úszás, 26,4\% délután úszásoktatás céljait szolgálja. Az uszodák 29\%-ában kap helyet a gyógytorna, és 8\%-ukban babaúszásra is van lehetőség.

Szombati napokon az uszodák 61,7\%-ban egész nap nyitva állnak a lakosság előtt, ugyanakkor 35\%-ukban úszóversenyekre kerül sor. Vasárnap 61,7\%-a egész nap, további $11,4 \%$ valamilyen rész időszakban, de nyitva tart a lakosság szolgálata érdekében. A babaúszás hétvégén is lehetséges az uszodák 8-11\%-ában, illetve a nagyobb uszodákban a versenyek vasárnap is folytatódhatnak $(5 \%)$. 


\section{Megbeszélés és következtetések}

Számos nemzetközi vizsgálat foglalkozott azzal, hogy a vizes helyszínek milyen fontos szerepet töltenek be a közösség és az egyén életében. Ugyanakkor a kutatások jelentősebb hányada az ezzel kapcsolatos problémák feltárására szorítkozott, mint lehetséges balesetek (White és Hyde 2010), UV sugárzás káros hatásai (Geller, Glanz és munkatársai 2001), és a klór okozta tünetek (Zarzoso, Llana és PerezSoriano 2010). Kevesebbet tudunk azonban arról, hogy milyen pozitív hatást gyakorolnak az uszodák, fürdők a fizikai állapotra és a szociális kapcsolatokra. A fürdökomplexumok müködését vizsgáló kutatások rámutattak azok egészséggel és fittséggel, relaxációval és stresszoldással kapcsolatos pozitív hatásaira (Howat Alikaris és March 2012), melyet nemrégen lefolytatott magatartáskutatáson alapuló széles körü vizsgálatok is megerősítettek (Middlestadt, Anderson és Ramos, 2015).

Áttekintő tanulmányában Tanaka (2009) rámutatott arra, hogy az úszás optimális az idősek, az elhízottak, a terhesek és mindazok számára, akiknek problémáik vannak a szárazföldi fizikai aktivitás okozta megterheléssel, valamint hogy az úszás javítja a magas vérnyomást, az inzulin érzékenységet és általános közérzetet. Ausztráliai kutatók azt találták, hogy azok a gyerekek, akik kültéri medencében úsztak, kevesebbet hiányoztak társaiknál az iskolából és a szüleik öket boldogabbnak ítélték (Lehman, Tennant és munkatársai 2003).

Az érintett megyékben, a legtöbb halálozást okozó betegségek közül több prevenció révén kedvezően befolyásolható lehetne. Mindenképpen fontos tehát az egészséges életmódra nevelés, az egészségügyi ismeretek lakossághoz történő eljuttatása egészségfejlesztési programok révén.

Tekintettel arra, hogy Magyarországon az úszás a népszerü sportágak közé tartozik (ennek okai között egyrészt megtalálhatjuk annak olimpiai- és világversenyeken való eredményességét, valamint a valamilyen egészségügyi okból kevésbé terhelhető szervezet számára is végezhetőségét, és a viszonylag alacsony jövedelmüek számára történő elérhetőségét is (Kith, Csernoch és Balatoni 2014), azt már iskolás korban célszerü megtanulni. Vizsgálataink rámutattak, hogy az Észak-alföldi régióban saját megítélés alapján az uszodák kihasználtsága 60-70\%-os, de ne feledkezzünk meg arról, hogy a létesítmények 17,6\%-a esetében jelent meg célként a létesítéskor az iskolai úszásoktatás, az esetek 35,3\%-ban a lakossági úszás kiszolgálása volt az alapvető indok. Ugyanakkor a jelenlegi foglalkozások megoszlásának elemzése az iskolai úszás 82,4\%-os részarányát mutatta. A saját uszodával rendelkező települések közül 6 db lakossága nem haladja meg az ötezer fót és további 8 település lakosságszáma 5000 és 10000 fő közötti, ahol a 0-14 éves korcsoport létszáma nem éri el a 750 illetve 1500 föt. Az uszodák lehetőséget biztosítanak mind az iskolai úszásnak, mind a lakossági úszásnak, de teret kap a gyógytorna, a délutáni úszásoktatás is, hétvégén pedig a lakossági úszás mellett az úszóversenyek. A nyitva tartás alapvetően napközben és este ad lehetőséget a felnőtt lakosságnak a használatra, az uszodák 21\%-a nyit ki reggel 6 órakor, vagy azt megelőzően, annak érdekében, hogy a munkába járó korosztály esetleg úszással kezdhesse a napját, vagy az iskola előtt még egy edzés is lehetséges legyen. 
A fejlett társadalmakban a gazdasági jólét erősödésével egyre nagyobb igény mutatkozik az egészséges életmód iránt. A sportolási szokásokat vizsgáló kutatások alapján megállapítható, hogy az úszás nemcsak a fiatalabb, hanem az idősebb korosztályoknál is az egyik legkedveltebb sportágak közé tartozik. Ezért az uszodák megléte, fenntartása, újak építése kiemel szempont a lakosság egészséges életmódjának fejlesztése érdekében. A jelenlegi uszodák száma nem elegendő a régió 587 általános iskolája számára, de az uszodaépítési program megvalósulásával az úszásoktatás egyre több iskola tantervébe épülhet be.

\section{Irodalomjegyzék}

1. Balatoni Ildikó, Kith Nikoletta, Csernoch László (2016): Időskori sportolási szokások vizsgálata Észak-kelet Magyarországon. Magyar Sporttudományi Szemle, (4), 17:4-8.

2. Baranowski T, Anderson C, Carmack C (1998): Mediating variable framework in physical activity interventions. How are we doing? How might we do better? American Journal of Preventive Medicine, (15), 4: 266-297. DOI: https://doi.org/10.1016/s0749-3797(98)00080-4

3. Brownson RC, Hoehner CM, Day K, Forsyth A, Sallis JF (2009): Measuring the built environment for physical activity: state of the science. American Journal of Preventive Medicine, (36), 4S: S99-S123. DOI:

https://doi.org/10.1016/j.amepre.2009.01.005

4. Brug J, van Lenthe FJ, Kremers SPJ. (2006): Revisiting Kurt Lewin: how to gain insight into environmental correlates of obesogenic behaviors. American Journal of Preventive Medicine, (31), 6: 525-529. DOI:

https://doi.org/10.1016/j.amepre.2006.08.016

5. Cauwenberg JV, Bourdeaudhuij ID, Meester FD, Dyck DV, Salmon J, Clarys P, Deforche B (2011): Relationship between the physical environment and physical activity in older adults: A systematic review. Health\&Place, 17: 458469. DOI: https://doi.org/10.1016/j.healthplace.2010.11.010

6. Davison KK, Lawson CT (2006): Do attributes in the physical environment influence children's physical activity? A review of the literature. International Journal of Behavioral Nutrition and Physical Activity, 3: 19. DOI: https://doi.org/10.1186/1479-5868-3-19

7. Edwardson CL, Gorely T (2010): Parental influences on different types and intensities of physical activity in youth: A systematic review. Psychology of Sport and Exercise, (11), 6: 522-535. DOI: https://doi.org/10.1016/j.psychsport.2010.05.001

8. Geller AC, Glanz K, Shigaki MS, Isnec MR, Sun T, Maddock J (2001): Impact of skin cancer prevention on outdoor aquatics staff: the Pool Cool program in Hawaii and Massachusetts. Preventive Medicine, (33), 3: 155-171. DOI: https://doi.org/10.1006/pmed.2001.0870

9. Hallal PC, Anderson LB, Bull FC, Guthold R, Haskell W, Ekelund U, Lancet Physical Activity Series Working Group (2012): Global physical activity levels: 
surveillance progress, pitfalls, and prospects. Lancet, (380), 9838:247-57. DOI: https://doi.org/10.1016/s0140-6736(12)60646-1

10. Howat G, Alikaris J, March H (2012): Health-related benefits: their influence on loyalty and physical activity participation in Austrlian public aquatic centres. International Journal of Sport Management and Marketing, (12), 1: 73-92. DOI: https://doi.org/10.1504/ijsmm.2012.051253

11. Kith Nikoletta, Csernoch László, Balatoni Ildikó (2014): Sport habits in NorthEastern Hungary. Journal of Health Sciences, (4), 13: 46-59.

12. Kohl HW, Craig CL, Lambert EV, Inoue S. Alkandari JR, Leetongin G, Kahlmeier S (2012): The pandemic of physical inactivity: global action for public health. Lancet, (380), 9838: 294-305. DOI: https://doi.org/10.1016/s0140-6736(12)60898-8

13. Központi Statisztikai Hivatal (2017): Tájékoztatási adatbázis. from: http://statinfo.ksh.hu (Letöltve: 2018. 12. 04.)

14. Központi Statisztikai Hivatal (2017): STADAT from: http://www.ksh.hu/docs/hun/xstadat/xstadat_eves/i_wdsd008.html (Letöltve: 2018. 12. 04.)

15. Központi Statisztikai Hivatal (2017): Statinfo; from: http://statinfo.ksh.hu/Statinfo/index.jsp (Letöltve: 2018. 12. 04.)

16. Központi Statisztikai Hivatal (2019): Tájékoztatási adatbázis. from: http://statinfo.ksh.hu (Letöltve: 2019. 03. 20.)

17. Lehman D, Tennant MT, Silva DT, McAullay FL, Coates H, Stanley FJ (2003): Benefits of swimming pools in two remote Aboriginal communities in Western Australia: an intervention study. BMJ, (327), 7412: 415-419. DOI: https://doi.org/10.1136/bmj.327.7412.415

18. Middlestadt SE, Anderson A, Ramos WD (2015): Beliefs about using an outdoor pool: Understanding perceptions of placeint he context of a recreational environment to improve health. Health \& Place, 34:1-8. DOI: https://doi.org/10.1016/j.healthplace.2015.03.007

19. Nemzeti Köznevelési Infrastruktúra Fejlesztési Program (2015): from: http://mnsk.hu/letesitmeny/nemzeti-koznevelesi-infrastruktura-fejlesztesiprogram/; (2018. 12. 04.)

20. Sallis JF, Prochaska JJ, Taylor WC (2000): A review of correlates of physical activity of children and adolescents. Medicine and Science in Sports Exercise, (32), 5: 963-975. DOI: https://doi.org/10.1097/00005768-200005000-00014

21. Jász-Nagykun-Szolnok Megyei Kormányhivatal (2018): Jász-Nagykun-Szolnok megye lakosságának egészségi állapotáról, az egészségromlást kiváltó vélelmezett okokról és a szükséges tennivalókról 2017. év adatai alapján. from: http://www.jnszm.hu/feltolt/File/kozgyules/kozlony/2018/nov/01_np_egeszsegi_ allapot_tajekoztato.pdf; (letöltve: 2018. 12. 04.)

22. Tanaka, H. (2009): Swimming exercise: impact of aquatic exercise on cardiovascular health. Sport Med., 39: 377-387. DOI: https://doi.org/10.2165/00007256-200939050-00004

23. Wendel-Vos W, Droomers M, Kremers S, Brug J, van Lenthe F (2007): Potential environmental determinants of physical activity in adults: a systematic 
review. Obesity Reviews, (8), 5: 425-440. DOI: https://doi.org/10.1111/j.1467789x.2007.00370.x

24. White KM, Hyde MK (2010): Swimming between the flags: a preliminary explorarion of the in fluences on Australians' intentions to swim between the flags at patrolled beaches. Accident Analysis and Prevention, (42), 6: 18311838. DOI: https://doi.org/10.1016/j.aap.2010.05.004

25. Zarzoso M, Llana S, Perez-Soriano P (2010): Potential negative effect of chlorinate swimming pool attendance on health of swimmers and associated staff. Biology of Sport, (27), 4: 233-240. DOI:

https://doi.org/10.5604/20831862.927465

26. 65/2007. (VI. 27.) OGY határozat a Sport XXI. Nemzeti Sportstratégiáról 